based on new sampling in the lacustrine shales and the detailed logging from the field season of 1988 is planned. A comparative study between the Upper Triassic - Lower Jurassic succession in Jameson Land and coeval successions in the Haltenbanken and Barents Sea areas of the Norwegian shelf is also planned.

Field work is to continue in 1989 . The main investigation will be in the central and northern parts of the basin starting with a lithofacies analysis of cores from Haltenbanken and Barents Sea (Norway).

Acknowledgements. The project is supported by British Petroleum Development, London.

\section{References}

Dam, G. 1988: Sedimentological studies of the fluviatile shallow marine Upper Triassic to Lower Jurassic succession in Jameson Land, East Greenland. Rapp. Grønlands geol. Unders. 140, 76-79.

Diem, B. 1985: Analytic method for estimating palaeowave climate and water depth from wave ripple marks. Sedimentology 32(5), 705-720.

Hallam, A. in press: A reevaluation of Jurassic eustasy in the light of new data and revised Exxon curve. In Wilgens, C. K. (edit.) Sea-level changes - an integrated approach. Spec. Publ. Soc. Econ. Paleontol. Mineral.

Harris, T. M. 1937: The fossil flora of Scoresby Sound, East Greenland. 5. Stratigraphic relations of the plant beds. Meddr Grønland 112(1), 1-114.
Pedersen, K. R. \& Lund, J. J. 1980: Palynology of the plantbearing Rhaetian to Hettangian Kap Stewart Formation, Scoresby Sund, East Greenland. Rev. Palaeobot. Palynol. 31, 1-69.

Piasecki, S. 1987: LECO/ROCK-EVAL screening analysis of the Upper Palaeozoic - Mesozoic sediments of Jameson Land, central East Greenland. Unpubl. intern. GGU rep., $60 \& 68$ pp.

Rosenkrantz, A. 1929: Preliminary account of the geology of the Scoresby Sound district. In Koch, L. The geology of East Greenland. Meddr Grønland 73(2), 135-154.

Stride, A. H. 1982: Offshore tidal sands: process and deposits, 213 pp. London: Chapman and Hall.

Surlyk, F., Callomon, J. H., Bromley, R. G. \& Birkelund, T. 1973: Stratigraphy of the Jurassic - Lower Cretaceous sediments of Jameson Land and Scoresby Land, East Greenland. Bull. Grønlands geol. Unders. 105 (also Meddr Grønland 193,5), $76 \mathrm{pp}$.

Surlyk, F., Clemmensen, L. B. \& Larsen, H. C. 1981: PostPaleozoic evolution of the East Greenland continental margin. In Kerr, J. W. \& Ferguson, A. J. (edit.) Geology of the North Atlantic borderlands. Mem. Can. Soc. Petrol. Geol. 7, 611-645.

Yang Chang-shu, Y. \& Sun Jia-song, S. 1988: Tidal sand ridges on East China Sea shelf. In de Boer, P. L., van Gelder, A. \& Nio, S. D. (edit.) Tide-influenced sedimentary environments and facies, 23-38. Dordrecht: D. Reidel Publ. Comp.

G. D. Grønlands Geologiske Undersøgelse, $\emptyset$ ster Voldgade 10, DK-1350 København K, Danmark.

\title{
Shallow core drilling of Upper Permian and Upper Triassic - Lower Jurassic potential reservoir rocks in central East Greenland
}

\author{
Flemming G. Christiansen and Lars Stemmerik
}

The aim of the 1988 shallow core drilling programme was to obtain unweathered and statistically representative samples of potential reservoir rocks to evaluate their diagenetic history. In the concession area held by ARCO (fig. 1) the youngest rocks expected to form a subsurface reservoir are the Upper Triassic - Lower Jurassic Kap Stewart and Neill Klinter Formations (Surlyk et al., 1986b; Stemmerik, 1988). At present, however, most interest is concentrated on the Upper Permian Wegener Halvø Formation (Surlyk et al., 1986a; Hurst et al., 1989) and, consequently, the programme focused on this formation in the type area (fig. 2). Additional drilling was carried out through the Kap Stewart Formation at a location close to Constable Pynt (fig. 1).
The drilling programme on Wegener Halvø was closely related to field investigations in the area by a joint ARCO, AGIP and GGU group (Stemmerik et al., 1989). Thus drilling on Wegener Halvø was restricted to a small, well-investigated area along the east coast of Wegener Halv $\varnothing$ (fig. 2) in order to get continuous samples through the core of two well-exposed but almost inaccessible mounds (fig. 3).

\section{The drilling programme}

The drilling programme was carried out with the helicopter-portable unit assembled by $\mathbf{J}$. Boserup and $\mathbf{A}$. Clausen at the Geological Survey of Greenland. This equipment has been modified a number of times as a 


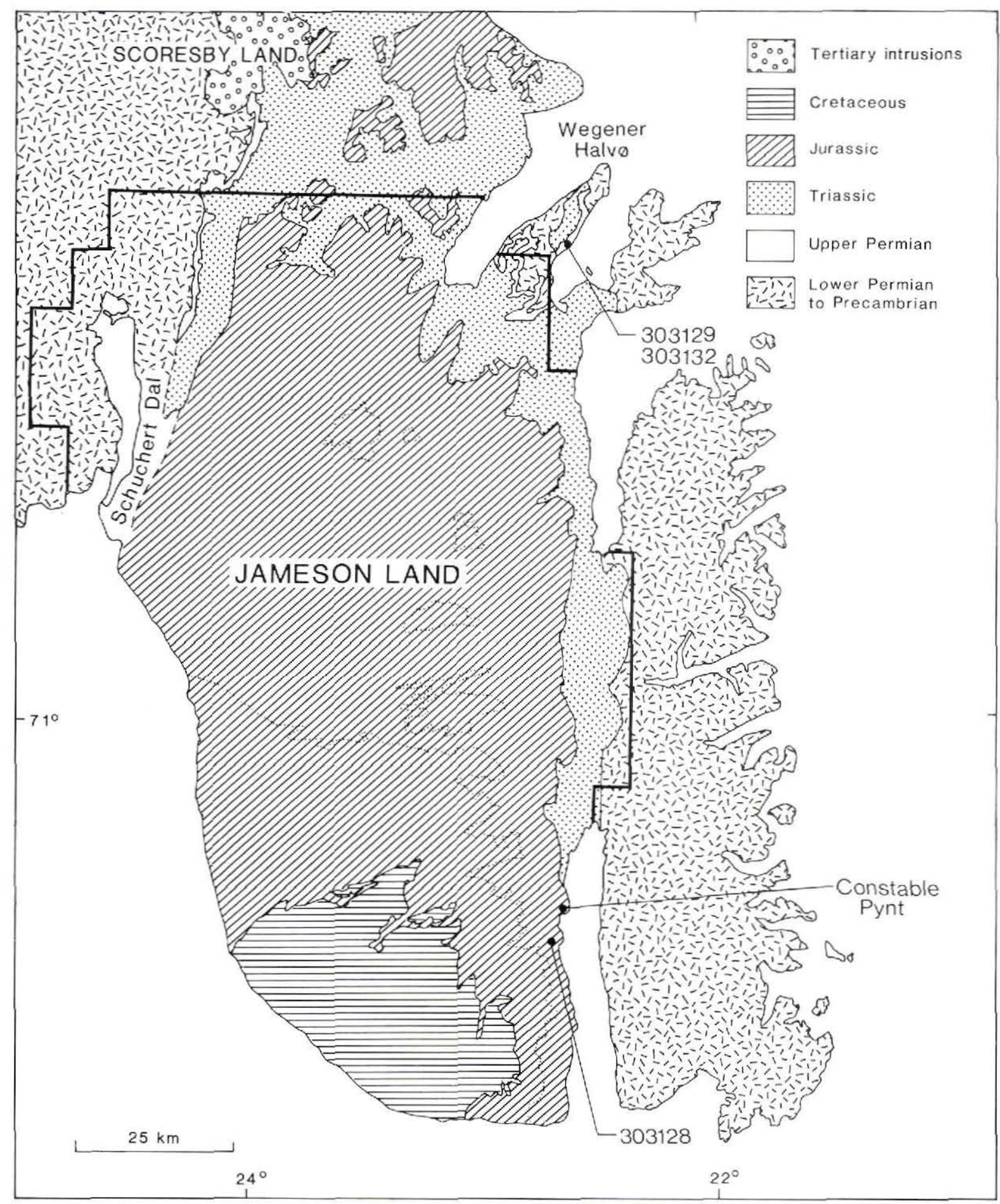

Fig. 1. Geological map of Jameson Land showing concession area of the ARCO group and position of the drill sites and the localities mentioned in the text. The geology is simplified from Surlyk et al. (1973). 
Table 1. Geological and technical description of different drill sites

\begin{tabular}{llllll}
\hline Drill site & Lithostratigraphy & Main lithology & Depth (metres) & Drill time * & Logs \\
\hline 88.1303128 & Kap Stewart Fm & sandstone, mudstone & 66.23 & July 18, 19, 20: $\sim 17 \mathrm{~h}$ & (Gamma) (Porosity) \\
88.2303129 & Wegener Halvø Fm & $\begin{array}{l}\text { limestone: flank beds } \\
\text { and mound core }\end{array}$ & 52.91 & July 27, 29: & $\sim 13 \mathrm{~h}$ \\
88.3303130 & $\begin{array}{l}\text { Wegener Halvø Fm/ limestone: mound core } \\
\text { Karstryggen Fm }\end{array}$ & 91.13 & Aug. 1, 2: & $\sim 19 \mathrm{~h}$ \\
88.4303131 & Wegener Halvø Fm limestone: flank beds & 23.12 & Aug. 4, 5: & $\sim 7 \mathrm{~h}$ \\
88.5303132 & $\begin{array}{l}\text { Schuchert Dal Fm/ } \\
\text { (Ravnefjeld Fm) }\end{array}$ & sandstone, (mudstone) & 74.48 & Aug. 8, 10/11: $\sim 17 \mathrm{~h}$ & Gamma, Porosity \\
\hline
\end{tabular}

* Includes ice-drilling Excludes mobilisation

consequence of previous drilling experience in Jameson Land, North Greenland, and on Traill $\emptyset$. In its present form the unit operates with a wire-line system giving a hole diameter of $46 \mathrm{~mm}$ and a core diameter of $30 \mathrm{~mm}$. Under optimal conditions depths of approximately 100 $m$ may be reached.

J. Boserup, A. Clausen and B. Mathiesen worked as technical personnel on the drilling team, while F. G. Christiansen, relieved occasionally by L. Stemmerik, acted as drill site geologist.

In total, five holes were drilled to depths of maximum $90 \mathrm{~m}$ with a cumulative length of approximately $310 \mathrm{~m}$ (Table 1). Except for the uppermost and lowermost metres in core 303128 , the core recovery was almost complete.

All cores were described at the drill site and sedimentological logs were made at scale 1:50. Gamma ray and neutron (porosity) logs were measured in two of the holes using equipment hired from the Geological Survey of Denmark (Table 1). This logging was carried out in open holes after completion of the drilling, a method which cannot be recommended in permafrost regions due to the high risk of losing the logging equipment in fractured or frozen zones. Although in this case the logs were completed without loss, an in-tube system with circulating hot water should be used under such conditions. The preliminary inspection of recorded logs shows good correlation with the sedimentological logs (see example in fig. 5).

Core pieces between 6 and $10 \mathrm{~cm}$ in length were canned at the drill site for possible future analysis of light hydrocarbons $\left(\mathrm{C}_{1}-\mathrm{C}_{8}\right)$, typically at 5 to $10 \mathrm{~m}$ in-

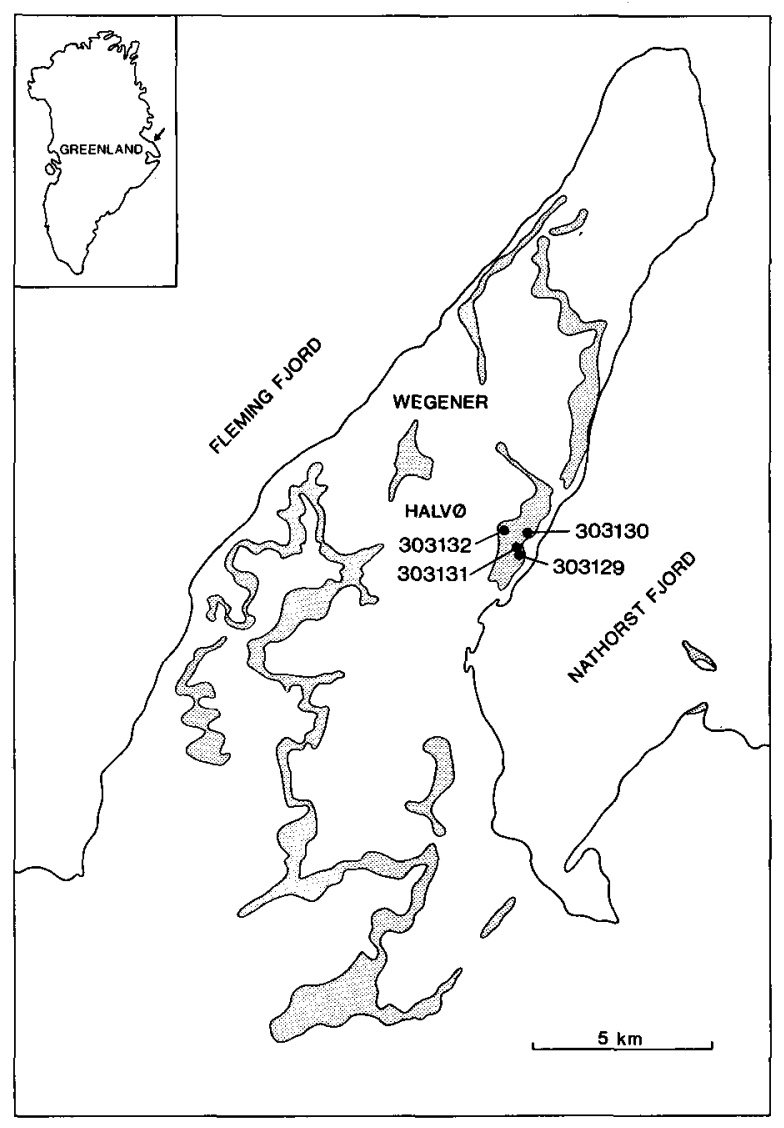

Fig. 2. Simplified geological map of Wegener Halvø showing the distribution of Upper Permian sediments and the position of the drill sites. 


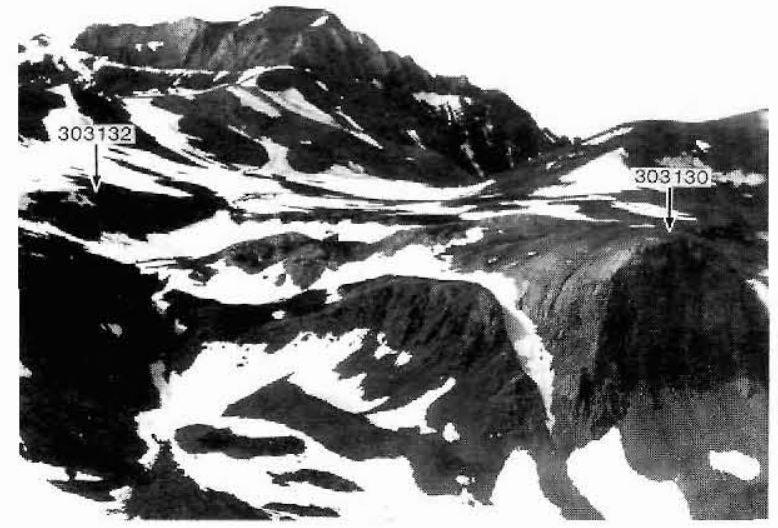

Fig. 3. View of the east coast of Wegener Halvø showing the position of drill sites 303130 and 303132 . Drill sites 303129 and 303131 are located immediately left (south) of the picture.

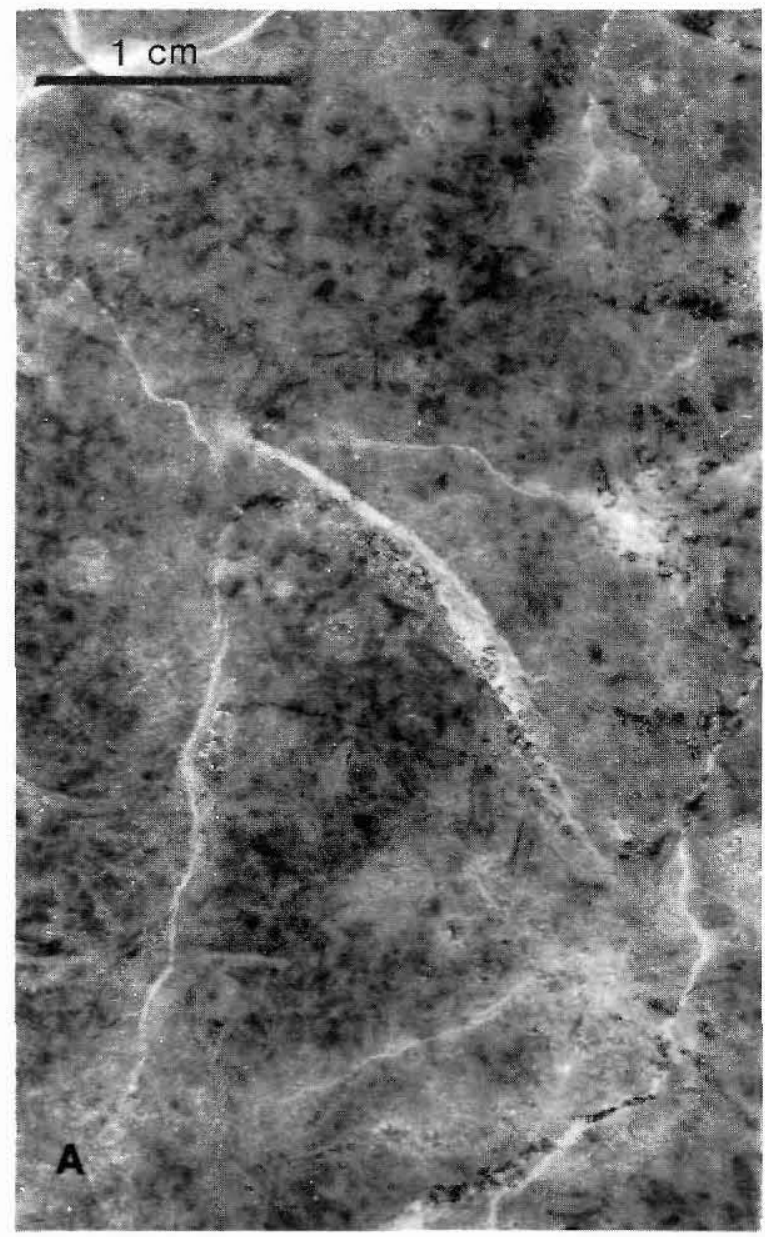

Fig. 4. A. Part of core 303129 showing typical mound core facies composed of fenestrate bryozoans and submarine cement. The bryozoans are dark due to bitumen impregnation. B. Part of core 303132 showing bioturbated fine-grained sandstone with silty intercalations. tervals. Small tubes of aluminium (designed for tooth paste) were used instead of traditional cans.

The first hole (303128) is located in Hareelv a few kilometres south-west of Constable Pynt (fig. 1). The core represents the upper third of the generally poorly exposed Upper Triassic - Lower Jurassic Kap Stewart Formation, immediately below the base of the Rævekløft Member (Neill Klinter Formation) (Surlyk et al., 1973; Dam, 1988). Lithologically, the core is composed mainly of pebbly sandstone, medium-grained sandstone and dark brownish to greenish mudstone, generally organized as fining-upward sequences a few metres thick. All lithological units are rich in coaly particles and plant fragments, and several of the mudstones display impressive well-preserved root systems.

The last four holes (303129 to 303132) are all located on Wegener Halvø south of Paradigmabjerg and were

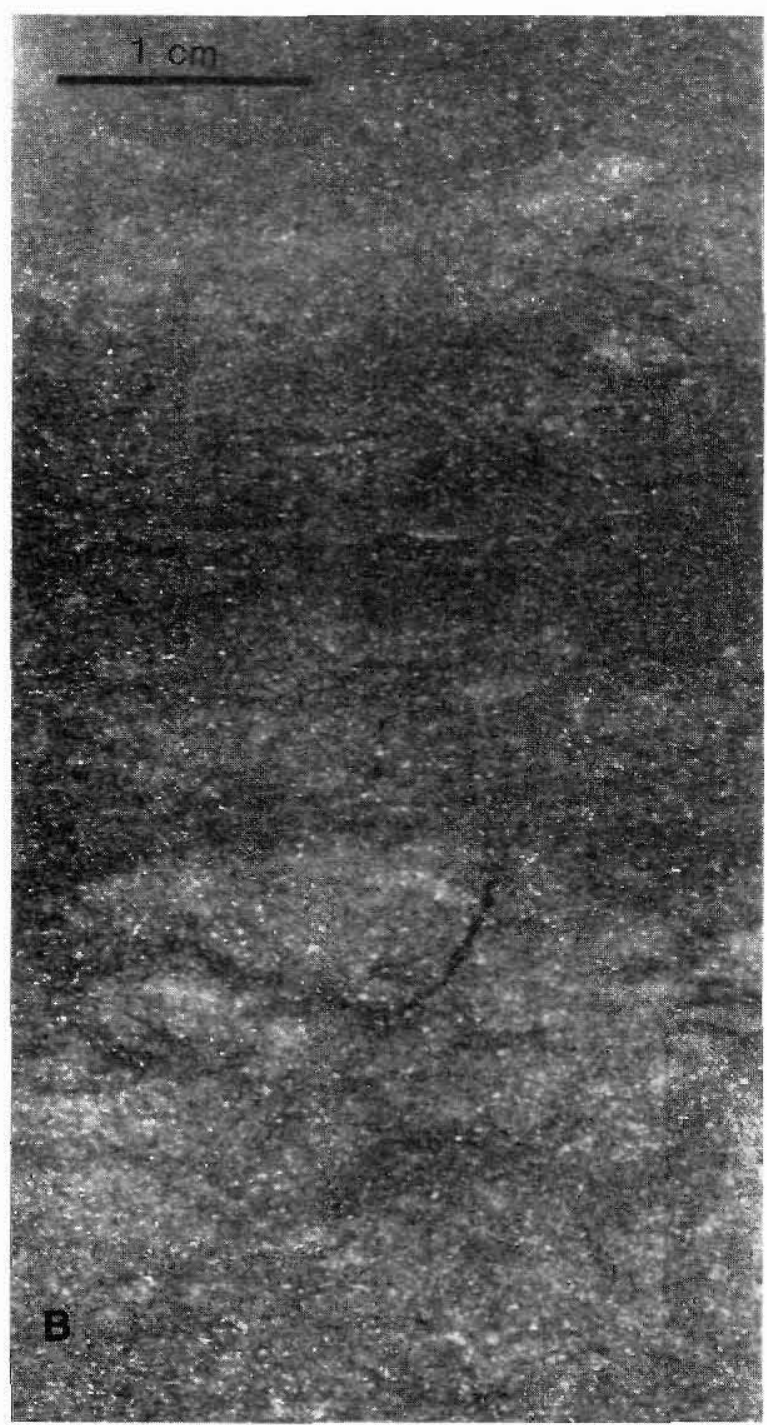


drilled from the same camp site (figs 2 and 3). Holes 303129 and 303131, which are separated by a distance of only $58 \mathrm{~m}$, both penetrate limestones of the Upper Permian Wegener Halvø Formation. In both cases brachiopod-rich flank beds occur in the upper part whereas mound core facies is observed in the lower part (fig. 4A). The latter is composed of bryozoans, submarine cement and bivalve-rich wackestone to packstone. Macroscopic bitumen is common from both holes and is typically observed in stylolites in the flank beds, in association with bryozoans in the core facies, and in late vugs and mineralized veins (calcite, baryte, fluorite, galena and $\mathrm{Cu}$ minerals).

The hitherto deepest hole drilled with the GGU equipment (303130) penetrates a variety of mound core facies of the Wegener Halvø Formation, including biogenic packstone dominated by bryozoans, bryozoansubmarine cement grainstone, oolitic grainstone, and the boundary to the underlying Karstryggen Formation (fig. 3). This is represented as an impressive karst surface with irregular limestone fragments in reddish marl and numerous thin fracture zones with Mn-rich dendrites.

The last hole (303132) is in an inter-mound position with the drill site located a few metres below the boundary between the Lower Triassic Wordie Creek Formation and the Upper Permian Schuchert Dal Formation (fig. 3). The uppermost $35 \mathrm{~m}$ of the core is composed of pale, medium- to coarse-grained, occasionally pebbly sandstone with a few intervals rich in brachiopods and carbonate debris (fig. 5). The lower half of the core is dominated by dark fine- to medium-grained sandstone, occasionally with muddy or silty intervals (fig. 4B). This part is strongly bioturbated. The boundary to the underlying black shale and carbonate (equivalent to the Ravnefjeld Formation) was reached a few metres above the base of the hole.

\section{Laboratory work and future studies}

The main aim of the planned laboratory work on the core material as well as on surface samples collected in the same area (see Stemmerik et al., 1989) is to provide information on the diagenetic history and reservoir potential of the limestones in the Wegener Halvø Formation.

The analytical programme includes petrographic studies of stained thin sections, cathode luminescence study of thin sections, carbon and oxygen isotope studies of various generations of carbonate minerals, and determination of petrophysical properties (porosity, permeability and density). Analyses of the light gas distribution and methane isotope composition will pro-
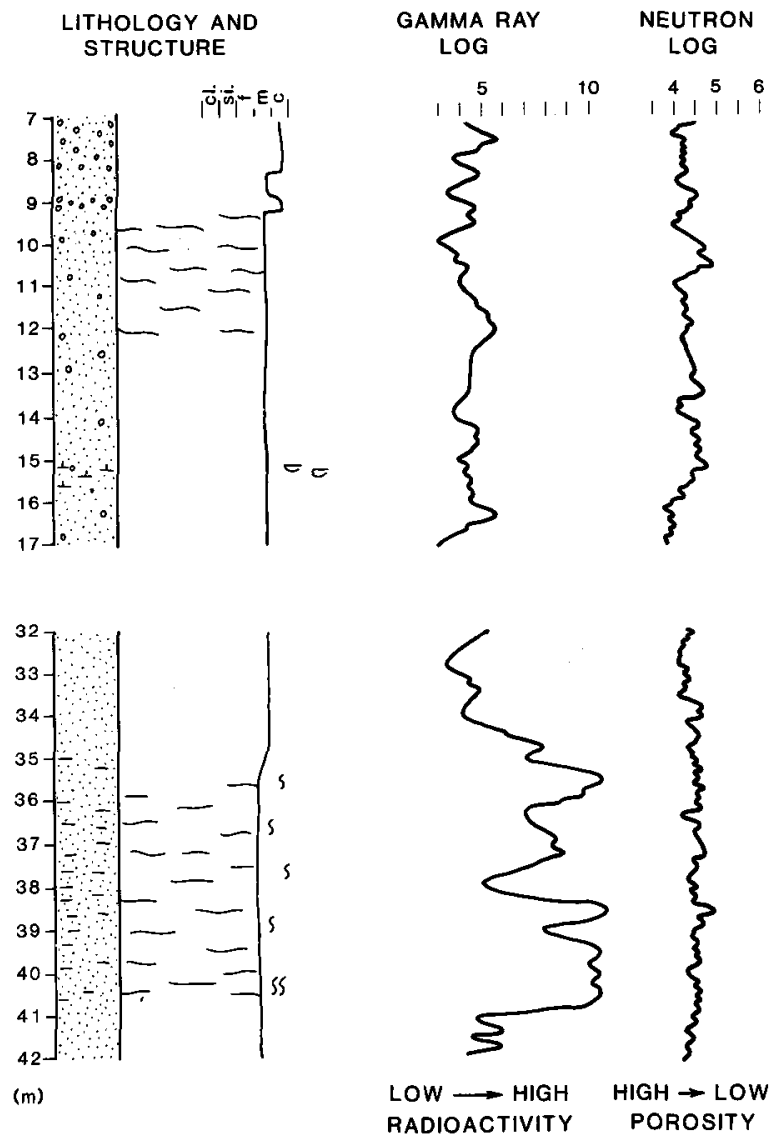

Fig. 5. Part of the sedimentological log of 303132 showing the correlation between the sedimentology and the gamma ray and neutron logs. The gamma log is indicated as counts per minute $\left(\times 10^{4}\right.$ ) with the following conditions: an integration time of 3.5 seconds, a crystal size of $1 \mathrm{inch}$, a diameter of $46 \mathrm{~mm}$, and a $\log$ speed of 1.5 metres per minute. The neutron $\log$ is indicated as counts per minute $\left(\times 10^{5}\right)$ under the same conditions.

vide information on the migration history and maturity of the hydrocarbons. Carbon isotope and gas chromatographic analyses of the observed bitumens will provide data necessary for correlation with source rocks and will throw light on the thermal and biogenic degradation history.

Acknowledgements. The drilling programme was financially supported by the Mineral Resources Administration for Greenland. Helicopter support was provided by ARCO Greenland A/S and operated from Constable Pynt. V. Hermansen, N. Turner, J. Halskov and B. S. Hansen helped prepare the manuscript and figures. 


\section{References}

Dam, G. 1988: Sedimentological studies of the fluviatile shallow marine Upper Triassic to Lower Jurassic succession in Jameson Land, East Greenland. Rapp. Grønlands geol. Unders. 140, 76-79.

Hurst, J. M., Scholle, P. A. \& Stemmerik, L. 1989: Submarine cemented bryozoan mounds, Upper Permian, Devondal, East Greenland. Mem. Can. Soc. Petrol. Geol. 13.

Stemmerik, L. 1988: A preliminary study of the porosity and permeability of limestones and sandstones in the Jameson Land area, central East Greenland. Rapp. Grønlands geol. Unders. 140, 80-84.

Stemmerik, L., Scholle, P. A., Thomas, E., Amendolia, M., Henk, F. H. \& Uncini, G. 1989: Facies mapping and reservoir evaluation of the Upper Permian Wegener Halvø Formation in Wegener Halvø, East Greenland. Rapp. Grønlands geol. Unders. 145 (this volume).

Surlyk, F. 1983: Source rock sampling, stratigraphical and sedimentological studies in the Upper Palaeozoic of the Jameson Land basin, East Greenland. Rapp. Grønlands geol. Unders. $115,88-93$.
Surlyk, F., Callomon, J. H., Bromley, R. G. \& Birkelund, T. 1973: Stratigraphy of the Jurassic - Lower Cretaceous sediments of Jameson Land and Scoresby Land, East Greenland. Bull. Gronlands geol. Unders. 105, $76 \mathrm{pp}$.

Surlyk, F., Hurst, J. M., Piasecki, S., Rolle, F., Scholle, P. A., Stemmerik, L. \& Thomsen, E. 1986a: The Permian of the western margin of the Greenland Sea - a future exploration target. In Halbouty, M. T. (edit.) Future petroleum provinces of the world. Mem. Am. Ass. Petrol. Geol. 40, 629659.

Surlyk, F, Piasecki, S. \& Rolle, F. 1986b: Initiation of petroleum exploration in Jameson Land, East Greenland. Rapp. Grønlands geol. Unders. 128, 103-121.

\title{
Facies mapping and reservoir evaluation of the Upper Permian Wegener Halvø Formation in Wegener Halvø, East Greenland
}

\author{
Lars Stemmerik, Peter A. Scholle, Elizabeth Thomas, \\ Massimo Amendolia, F. H. Henk and Giuseppe Uncini
}

Field work was carried out from 17 July to 3 August by a joint group from ARCO, AGIP and GGU to evaluate the reservoir potential of the Upper Permian limestones in Wegener Halvø (fig. 1). The group was based south of Paradigmabjerg (fig. 1) and had a Bell 206 helicopter available full-time during the entire period. Logistic support was provided by the ARCO base at Constable Pynt.

The Upper Permian limestones in the Wegener Halv $\varnothing$ area have been investigated previously by GGU (Stemmerik, 1979; Surlyk, 1983; Surlyk et al., 1984a,b, 1986a; Hurst et al., 1989). Diagenetic studies of the limestones (Scholle, 1986; Hurst et al., 1989) indicate that reservoir properties are expected mainly to occur in the bryozoan-cement mounds of the Wegener Halv $\emptyset$ Formation. Accordingly, the 1988 programme concentrated on more detailed studies of these mounds and included a shallow drilling programme conducted by GGU (see Christiansen \& Stemmerik, 1989).

\section{Facies mapping}

The facies mapping of the Wegener Halvø Formation involved both detailed mapping of individual mound complexes and mapping of the regional distribution of mounds. The overall facies distribution and thickness variation is well delineated by Surlyk et al. (1986a) and Hurst et al. (1989). The present study confirmed the overall thinning of the formation to the west, although local variations make the pattern more complex than previously indicated. This is particularly the case along the east coast of the peninsula where the location of the larger mounds was found to be controlled by the topography of the karst surface of the underlying Karstryggen Formation.

The mounds have a complex depositional history and include a variety of shallow marine to deeper water facies. In addition to these facies recorded by Surlyk $e t$ al. (1986a) and Hurst et al. (1989), a volumetrically important facies composed of calcite pseudomorphs after botryoidal aragonite with a few volume percent bryozoans was found (fig. 2). This facies represents the core of the largest mounds in the area and is accordingly restricted to the eastern part of the peninsula (fig. 1).

Four different types of mound were tentatively distinguished on the basis of facies distribution and types of post-mound events. 